\title{
Effect of Glucose Deprivation and Acute Glutamate Exposure in Cultured Retinal Cells
}

\author{
Ana Cristina Rego, Filipe Miguel Areias, Maria Sancha Santos, and Catarina R. Oliveira ${ }^{1}$ \\ Center for Neurosciences of Coimbra, Faculty of Medicineand Department of Zool ogy, University of Coimbra, 3000 Coimbra, Portugal
}

Received J anuary 13, 1998; accepted May 26, 1998

The relationship between bioenergetics and the glutamate system was analyzed in a neuronal model of retinal cells in culture, submitted to glucose deprivation and exposed to glutamate for $\mathbf{2 h}$, and compared with exposure to glutamate in the presence of glucose. Under glucose deprivation, a reduction (about 1.1-fold) in the energy charge of the cells occurred, probably as a result of a decrement (by about $75 \%$ ) in the cellular redox efficacy, as determined by the 3-(4,5-di methylthiazol-2-yl)-2,5-diphenyl tetrazolium bromide (MTT) test. In the absence of glucose, exposure of retinal cells to 10 $\mu M$ glutamate potentiated the reduction in the energy charge (by about 1.2-fold) and induced a significant increase in the uptake of ${ }^{45} \mathrm{Ca}^{2+}$ by the cells (1.3-fold), although no significant changes were observed in the presence of glucose. Under glucose deprivation, 100 $\mu M$ glutamate caused an irreversible cell membrane damage, as shown by the significant increase in lactate dehydrogenase (LDH) leakage (about 1.8-fold). A significant increase in membrane depolarization, measured by the reduction of $\left[{ }^{3} \mathrm{H}\right]$ tetraphenylphosphonium $^{+}\left(\left[^{3} \mathrm{H}\right] \mathrm{TPP}^{+}\right)$uptake, was also observed after glutamate exposure in the absence of glucose. In the presence of glucose, high glutamate concentrations (10 $\mathrm{mM}$ ) induced a major increase in $\mathrm{Ca}^{2+}$ entry into the cells and membrane depolarization, without affecting the energy charge or cell survival. In contrast, in the absence of glucose, $10 \mathrm{mM}$ glutamate did not alter $\mathrm{Ca}^{2+}$ accumulation by the cells and a smaller decrease in membrane potential occurred, as compared to $100 \mu \mathrm{M}$ glutamate exposure. Data shown in this study suggest that during a prolonged $(2 \mathrm{~h})$ and acute exposure to high glutamate (10 $\mathrm{mM})$, under glucose deprivation conditions, the neuronal systems have "adaptive" mechanisms that allow the survival of cells. These findings may have implications in neuronal degeneration occurring during brain ischemia. $\odot 1998$ Academic Press

Key Words: $\mathrm{Ca}^{2+}$ uptake; cell injury; energy charge; glucose deprivation; glutamate; membrane potential; retinal cells

\footnotetext{
${ }^{1}$ To whom correspondence and reprint requests should be addressed. Fax: 351-39-822776.
}

\section{INTRODUCTION}

L-Glutamateand related excitatory amino acids (EAA) play an essential role in fast synaptic transmission and plasticity in the central nervous system, by interacting with glutamate receptors. The maintenance of glutamate extracellular concentrations below toxic levels is facilitated, in neuronal terminals or glial cells, by its reuptake via the high-affinity transport system. Otherwise, an excessive stimulation of ionotropic glutamate receptors induces the alteration of $\mathrm{Ca}^{2+}$ homeostasis $(5,8)$, a proposed initial step for neuronal degeneration following ischemia, hypoglycemia, or trauma (7). Moreover, excitotoxicity, resulting from the dysfunction of the EAA system, is a mechanism thought to take place in several acute neurodegenerative diseases and finally leads to neuronal death. Previously, we showed that a decreased glucose metabolism, induced in the presence of iodoacetic acid or deoxyglucose, significantly decreased the adenylate energy charge in retinal cells in culture, used as neuronal models (19). Furthermore, in vitro conditions of hypoxia or ischemia in the retina system were shown to increase the release of glutamate $(17,19,24)$, which seems to have a fundamental role in enhancing the neuronal damage.

Early work on glutamate toxicity has intensively focused on defining the contribution of ionotropic glutamate receptors $(4,5,8)$, in order to search for good pharmacological tools that could prevent from glutamate excitotoxicity. During many neurodegenerative diseases and ischemia situations, glucose and/or oxygen deprivation combines with an excessive release of glutamate, followed by neurotoxic effects. Because excitotoxicity in the retina system has been focused on delayed neuronal damage $(8,20)$, in this study we analyzed some of the intracellular mechanisms associated with an acute exposure to glutamate under conditions of glucose deprivation in cultures of retinal cells, used as neuronal models. We focused both on low (10-100 $\mu \mathrm{M})$ glutamate concentrations, known to be involved with receptors activation, and high (10 mM) glutamate concentrations, suggested to occur locally under pathophysiological conditions, in the ischemic 
core or in the vicinity of a traumaticinjury (12). For this purpose, we analyzed the glutamate-induced alterations of energy levels, $\mathrm{Ca}^{2+}$ uptake, and membrane potential, which were compared with changes in cell viability, determined by the release of LDH and the efficacy to reduce MTT. The present data show that under glucose deprivation, major glutamate-mediated cell injury is observed in the presence of low glutamate concentrations $(10-100 \mu \mathrm{M})$, shown to be sufficient to activate the glutamate receptors, whereas in the presence of high glutamate concentrations (10 mM) neuronal damage is not further increased. Theanalysis of the cellular processes involved in neurodegeneration, during glutamate exposure, should give new insights on the excitotoxic neuronal death occurring under hypoglycemia or ischemia situations.

\section{MATERIALS AND METHODS}

\section{Materials}

Basal medium of Eagle (Earle's salts; BME) was purchased from Sigma Chemical Co. (St. Louis, Mo.), fetal calf serum was obtained from BioChrom KG (Berlin, Germany), and trypsin was from GIBCO (Paisley; UK). [ $\left.{ }^{3} \mathrm{H}\right]$ Tetraphenyl phosphonium ${ }^{+}\left(\left[{ }^{3} \mathrm{H}\right] \mathrm{TPP}+; 23\right.$ $\mathrm{Ci} / \mathrm{mmol}$, as bromide salt) and ${ }^{45} \mathrm{Ca}^{2+}(13 \mathrm{mCi} / \mathrm{mg}$ calcium) were obtained from Amersham International (Amersham Centre, UK). All other chemicals used were purchased from Sigma Chemical Co.

\section{Culture of Retinal Cells}

Retinal cells were obtained from 8-day-old chick embryos. Theretinas weretrypsinized (0.1\%) in Hank's medium without $\mathrm{Ca}^{2+}$ or $\mathrm{Mg}^{2+}$, for $15 \mathrm{~min}$, at $37^{\circ} \mathrm{C}$, and then centrifuged at $500 \mathrm{~g}$, for $1 \mathrm{~min}$ (room temperature). The cells were resuspended in BME culture medium, supplemented with $5 \%$ fetal calf serum, $100 \mathrm{U} / \mathrm{ml}$ penicillin, and $100 \mathrm{mg} / \mathrm{ml}$ streptomycin, and buffered with $25 \mathrm{mM}$ Hepes and $10 \mathrm{mM} \mathrm{NaHCO}$. Retinal cells were plated at a density of $0.44 \times 10^{6}$ cells $/ \mathrm{cm}^{2}$ on Costar 12-multiwell plates, previously coated with polyL-lysine. The cells were maintained in culture for 5-6 days at $37^{\circ} \mathrm{C}$ in an atmosphere of $95 \%$ air and $5 \% \mathrm{CO}_{2}$. A cell preparation similar to the one used in this work was shown to contain a significant percentage of amacrine-like neurons and neurons resembling bipolar cells and only a few glial cells (1, 10).

\section{Incubation of Retinal Cells}

Retinal cells were washed and incubated in $\mathrm{Na}^{+}$ medium, containing (in $\mathrm{mM}$ ): $140 \mathrm{NaCl}, 5 \mathrm{KCl}, 1.5$ $\mathrm{CaCl}_{2}, 1 \mathrm{MgCl}_{2}, 1 \mathrm{NaH}_{2} \mathrm{PO}_{4}, 5.6$ glucose, and 20 Hepes, at $\mathrm{pH} 7.4,37^{\circ} \mathrm{C}$, for $15 \mathrm{~min}$. Glucose deprivation conditions were induced for $30 \mathrm{~min}$ (- glucose) before glutamate exposure. Other cells were incubated with medium containing glucose (+ glucose). Then, Lglutamate $(10 \mu \mathrm{M}, 100 \mu \mathrm{M}$, or $10 \mathrm{mM})$ was incubated, respectively, in the absence or in the presence of glucose, for $2 \mathrm{~h}$, at $37^{\circ} \mathrm{C}$. Control retinal cells were incubated in the absence of glutamate.

\section{Determination of Adenine Nucleotides}

Retinal cells were extracted with $0.3 \mathrm{M}$ perchloric acid right after the incubation with glutamate. Then, the acid extract was centrifuged at $15,800 \mathrm{~g}$, for $5 \mathrm{~min}$, at $0-4^{\circ} \mathrm{C}$. The resulting pellets were analyzed for total protein content (21), whereas the supernatants were neutralized with $10 \mathrm{M} \mathrm{KOH}$ in $5 \mathrm{M}$ Tris. After neutralization the samples were centrifuged at $15,800 \mathrm{~g}$, for 10 $\mathrm{min}$, at $0-4^{\circ} \mathrm{C}$. The supernatants were assayed for ATP, ADP, and AMP, by separation in a reverse phase HPLC (23). The adenine nucleotides were el uted at a flow rate of $1.2 \mathrm{ml} / \mathrm{min}$ with $100 \mathrm{mM} \mathrm{KH_{2 }} \mathrm{PO}_{4}, \mathrm{pH} 7.4$, and $1 \%$ methanol, and detected at $254 \mathrm{~nm}$, for $6 \mathrm{~min}$. The adenylate energy charge (EC) was calculated according to the formula (3):

$$
E C=(A T P+0.5 A D P) /(A T P+A D P+A M P) .
$$

\section{${ }^{45} \mathrm{Ca}^{2+}$ Uptake Measurements}

${ }^{45} \mathrm{Ca}^{2+}(1.5 \mu \mathrm{Ci} / \mathrm{ml})$ uptake measurements were performed during the glutamate incubation, for $2 \mathrm{~h}\left(37^{\circ} \mathrm{C}\right)$, in the presence or in the absence of glucose. When present, $5 \mu \mathrm{M}$ nitrendipine, a blocker of L-type $\mathrm{Ca}^{2+}$ channels, was incubated for $30 \mathrm{~min}$ in the presence or in the absence of glucose and during the 2-h exposure to glutamate. The reaction was stopped by washing the cells twice with $1 \mathrm{mM} \mathrm{LaCl}$ and once with $1 \mathrm{mM} \mathrm{LaCl}_{3}$ and $1 \mathrm{mM}$ EGTA (prepared in $\mathrm{Na}^{+}$solution without $\mathrm{NaH}_{2} \mathrm{PO}_{4}$ or $\mathrm{CaCl}_{2}$ ). The cells were extracted with $0.1 \mathrm{M}$ $\mathrm{NaOH}$ and the radioactivity of ${ }^{45} \mathrm{Ca}^{2+}$ retained by retinal cells was determined by scintillation spectroscopy and further expressed as dpm/ $10^{6}$ cells.

\section{$\left[{ }^{3} \mathrm{H}\right] \mathrm{TPP}+$ Uptake Measurements}

$\left[{ }^{3} \mathrm{H}\right] \mathrm{TPP}+(0.25 \mu \mathrm{Ci} / \mathrm{ml})$ was incubated after the treatment of retinal cells with glutamate. Incubations of $\left[{ }^{3} \mathrm{H}\right] \mathrm{TPP}+{ }^{+}$were performed in $\mathrm{Na}^{+}$or $\mathrm{K}^{+}$medium $\left(\mathrm{Na}^{+}\right.$ was isoosmotically substituted by $\mathrm{K} \mathrm{Cl}$ ), for $15 \mathrm{~min}$, just before the steady-state level of TPP ${ }^{+}$accumulation by retinal neurons in culture (2), at $37^{\circ} \mathrm{C}$. The TPP ${ }^{+}$ uptake reaction was terminated by adding $10 \%$ TCA $(\mathrm{w} / \mathrm{v})$. Then the cells were centrifuged at $15,800 \mathrm{~g}$, for 2 min, and the radioactivity of the supernatant was determined by scintillation spectroscopy. The membrane potential, only across the plasma membrane, was determined by calculating the difference in the uptake of $\left.{ }^{3} \mathrm{H}\right] T \mathrm{PP}^{+}$in $\mathrm{Na}^{+}$and $\mathrm{K}^{+}$medium $(\mathrm{Na}-\mathrm{K})$, because $\mathrm{TPP}^{+}$accumulation after depolarization of the plasma 
membrane with $140 \mathrm{mM} \mathrm{K}{ }^{+}$mainly reflects the large negative mitochondrial membrane potential. The re sults were expressed as dpm/ $2 \times 10^{6}$ cells.

\section{Analysis of Cell Viability}

Experiments were performed to monitor the leakage of LDH (lactate dehydrogenase) or to follow the reduction of MTT (3-(4,5-dimethylthiazol-2-yl)-2,5-diphenyl tetrazolium bromide), which is based on the reduction capacity of mitochondrial dehydrogenases to reduce the MTT salt into formazan, an insoluble product (16).

LDH activity was measured spectrophotometrically by following the conversion of NADH to $\mathrm{NAD}^{+}$, at 340 $\mathrm{nm}$, as described elsewhere (19). LDH leakage to the extracellular medium was expressed as a percentage of total LDH activity.

The MTT assay consisted in the incubation of 0.5 $\mathrm{mg} / \mathrm{ml}$ MTT $(0.5 \mathrm{ml})$ dissolved in $\mathrm{Na}^{+}$medium in the absence or in the presence of glucose, during glutamate exposure, for $2 \mathrm{~h}$. At the end of the incubation at $37^{\circ} \mathrm{C}$, an equal volume of $0.04 \mathrm{M} \mathrm{HCl}$ in isopropanol was added, and the resulting mixture was recovered from the cell plates. The extent of MTT reduction was measured spectrophotometrically at $570 \mathrm{~nm}$. Cell toxicity was expressed as a percentage of OD of control cells, in the absence of glutamate, but in the presence of glucose.

\section{Data Analysis}

The results are the means \pm SEM of the indicated number of experiments. Statistical values $(P<0.05)$ were determined by the unpaired, two-tailed, Student's t test or by the one-way ANOVA with a Bonaferroni posttest, for multiple comparisons.

\section{RESULTS}

\section{Effect of Glutamate on theEnergy Charge of the Cells under Glucose Deprivation}

The effect of glutamate, under glucose-free conditions, was analyzed by determining the energy charge in retinal cells in culture (Fig. 1). In the presence of glucose, low (10 or $100 \mu \mathrm{M})$ or high $(10 \mathrm{mM})$ glutamate concentrations did not significantly alter the energy levels of the cells. However, in the absence of glucose, cells not submitted to glutamate exposure (controls) showed a significant reduction in the energy charge $(0.81 \pm 0.02, \mathrm{P}<0.01)$, as compared to controls in the presence of glucose $(0.89 \pm 0.02)$. Under glucose deprivation, larger decrements in the energy charge (EC of approximately 0.65), indicative of a significant decrease in ATP (not shown), were observed in the presence of glutamate ( $10 \mu \mathrm{M}$ and up to $10 \mathrm{mM})$. Under these conditions, the energy levels decreased significantly, as compared to the controls in the absence of

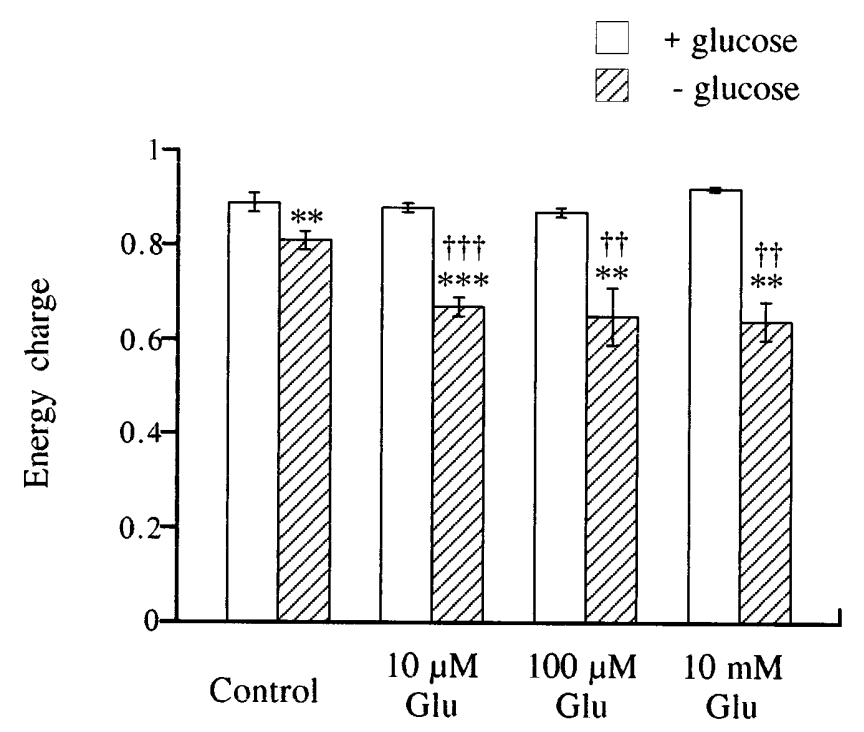

FIG. 1. Energy charge of retinal cells submitted to glutamate in the presence or in the absence of glucose. Adenylate energy charge was calculated by determining the intracellular levels of ATP, ADP, and AMP in retinal cells preincubated in the absence or in the presence of glucose for $30 \mathrm{~min}$, and further exposed to glutamate (10 $\mu \mathrm{M}, 100 \mu \mathrm{M}$, or $10 \mathrm{mM}$ ) for $2 \mathrm{~h}$, respectively, in glucose-free (glucose) or glucose-containing ( + glucose) medium, at $37^{\circ} \mathrm{C}$. Controls were incubated in the absence of glutamate. The data are the means \pm SEM of duplicates or triplicates from two to three experiments. Statistical significance: $* * P<0.01$ or $* * * P<0.001$ as compared to the control in the presence of glucose; ${ }^{\mathrm{t}} \mathrm{P}<0.01$ or ${ }^{\mathrm{tt} \mathrm{P}}<$ 0.001 as compared to the control in the absence of glucose.

glucose, indicating that exposure to glutamate potentiates the decrement of the energy charge caused by glucose deprivation (Fig. 1).

\section{Intracellular $\mathrm{Ca}^{2+}$ Accumulation after Glutamate Exposure under Glucose Deprivation}

In order to evaluate the intracellular mechanisms of glutamate injury that mediated the reduction in energy charge in retinal cells submitted to glucose deprivation, we studied the uptake of ${ }^{45} \mathrm{Ca}^{2+}$. In the presence of glucose, glutamate $(100 \mu \mathrm{M}$ or $10 \mathrm{mM})$ increased significantly the uptake of ${ }^{45} \mathrm{Ca}^{2+}$, as compared to the control (Fig. 2). Glucose deprivation, per se, did not significantly influence the entry of ${ }^{45} \mathrm{Ca}^{2+}$ in control retinal cells. However, exposure to $10 \mu \mathrm{M}$ glutamate, in the absence of glucose, increased significantly the uptake of ${ }^{45} \mathrm{Ca}^{2+}\left(599.0 \pm 30.0 \mathrm{dpm} / 10^{6}\right.$ cells, $\mathrm{P}<$ 0.001 ), as compared to $10 \mu \mathrm{M}$ glutamate in the presence of glucose ( $467.0 \pm 18.2 \mathrm{dpm} / 10^{6}$ cells). In the absence of glucose, $100 \mu \mathrm{M}$ glutamate (3094.7 $\pm 107.6 \mathrm{dpm} / 10^{6}$ cells) induced a maximal accumulation of ${ }^{45} \mathrm{Ca}^{2+}$. Thus, the ${ }^{45} \mathrm{Ca}^{2+}$ taken up after incubation with $10 \mathrm{mM}$ glutamate, in the absence of glucose, was significantly lower $(P<0.001)$, as compared to retinal cells incubated with the same concentration of glutamate in the presence of glucose (Fig. 2). Nitrendipine (5 $\mu \mathrm{M})$, a 
blocker of L-type $\mathrm{Ca}^{2+}$ channels, which was shown to play a major role on $\left[\mathrm{Ca}^{2+}\right]_{i}$ changes upon glutamate receptor activation in retinal cells in culture (6), did not significantly influence the intracellular accumulation of ${ }^{45} \mathrm{Ca}^{2+}$ after incubation with glutamate for $2 \mathrm{~h}$, in the presence or in the absence of glucose (data not shown).

\section{Alteration of MembranePolarization after Glutamate Exposurein the Absence of Glucose}

We also analyzed the al terations in membrane potential upon glutamate exposure, under normal or glucose deprivation conditions, by examining the uptake of $\left[{ }^{3} \mathrm{H}\right]$ TPP ${ }^{+}$in retinal neurons in culture (Fig. 3). TPP ${ }^{+}$is a permeant lipophilic cation that easily permeates the membrane and accumulates in cells, allowing an indirect evaluation of alterations in membrane potential (13). In the presence of glucose, the plasma membrane potential, represented by the difference of $\left[{ }^{3} \mathrm{H}\right] \mathrm{TPP}{ }^{+}$ uptake observed in $\mathrm{Na}^{+}$and $\mathrm{K}^{+}$medium ( $\left.\mathrm{Na}-\mathrm{K}\right)$, significantly decreased upon exposure to $10 \mathrm{mM}$ glutamate. Control retinal cells submitted to glucose-free medium showed a large decrease in membrane potential $\left(2737.0 \pm 222.4 \mathrm{dpm} / 2 \times 10^{6}\right.$ cells, $\left.\mathrm{P}<0.01\right)$, as compared to cells incubated in glucose medium (4434.1 $\pm 406.3 \mathrm{dpm} / 2 \times 10^{6}$ cells). Nevertheless, retinal neurons exposed to $100 \mu \mathrm{M}$ or $10 \mathrm{mM}$ glutamate, in the absence of glucose, showed a major membrane depolarization in comparison with controls under the same experimental conditions (Fig. 3). However,

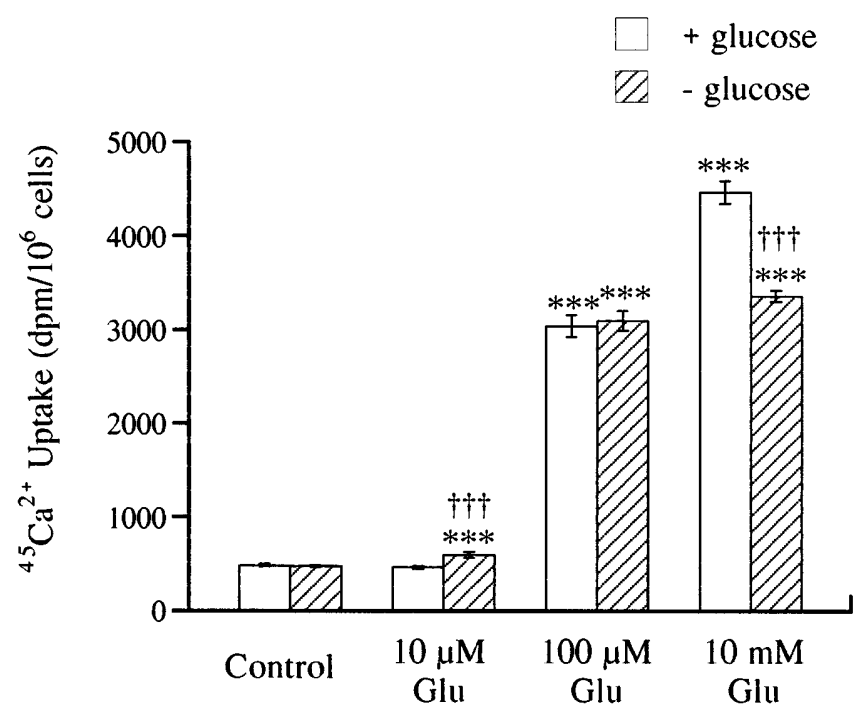

FIG. 2. Effect of glucose deprivation on the ${ }^{45} \mathrm{Ca}^{2+}$ uptake induced by glutamate. The ${ }^{45} \mathrm{Ca}^{2+}$ retained by retinal cells was measured upon glutamate $(10 \mu \mathrm{M}, 100 \mu \mathrm{M}$, or $10 \mathrm{mM})$ exposure for 2 $\mathrm{h}$, in the presence (+ glucose) or in the absence (- glucose) of glucose. Control cells were incubated in the absence of glutamate. Data are the means \pm SEM of triplicates from three experiments. Statistical significance: $* * * P<0.001$ as compared to the respective controls; $\mathrm{tttP}<0.001$ as compared to the respective data obtained in the presence of glucose, under similar experimental conditions.

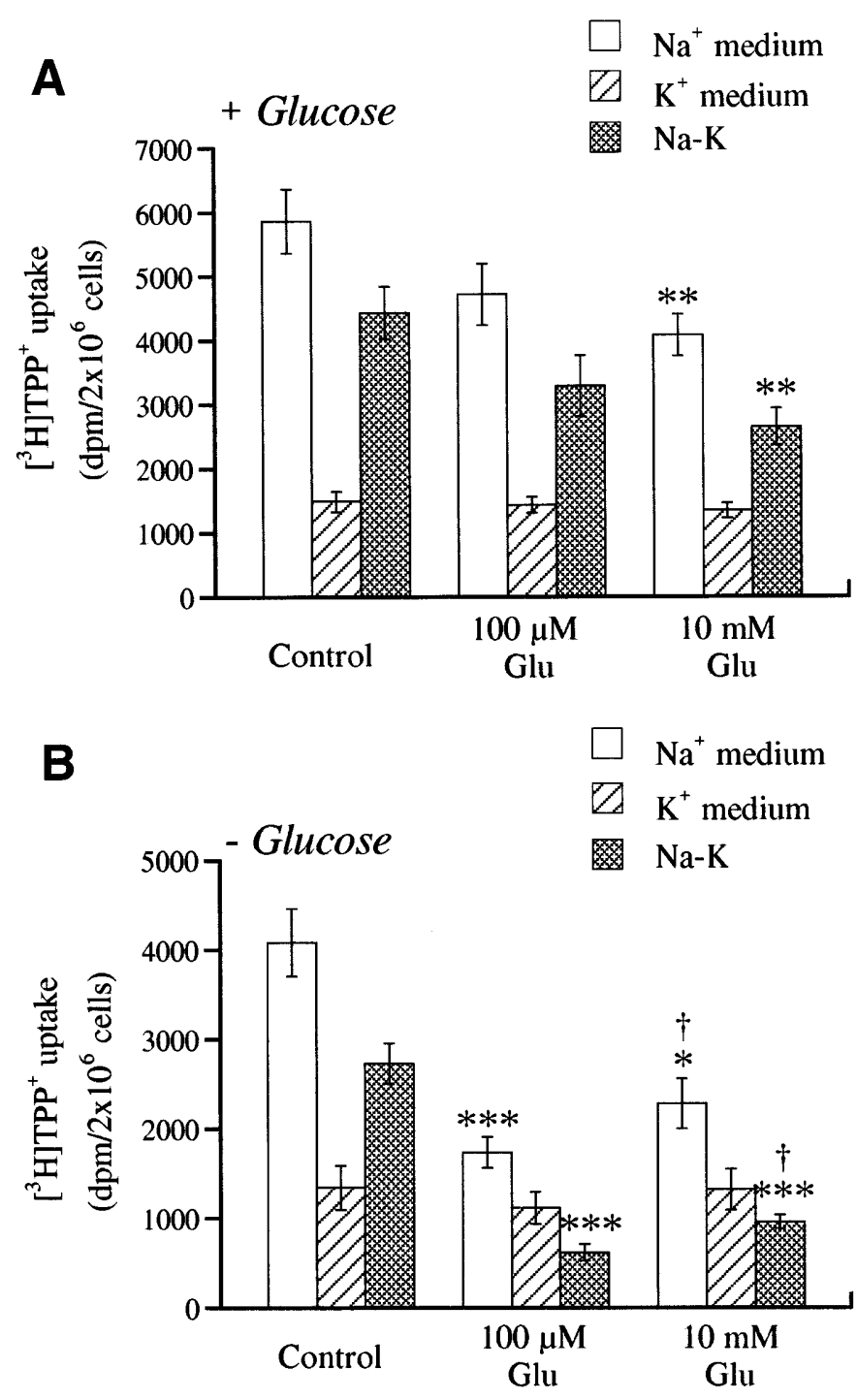

FIG. 3. Uptake of $\left[{ }^{3} \mathrm{H}\right] T \mathrm{PP}^{+}$upon glutamate exposure, in the presence or in the absence of glucose. Retinal cells were exposed to glutamate $(10 \mu \mathrm{M}, 100 \mu \mathrm{M}$, or $10 \mathrm{mM}$ Glu $)$ for $2 \mathrm{~h}$ in the presence (A) or in the absence (B) of glucose. $\left[{ }^{3} \mathrm{H}\right] \mathrm{TPP}{ }^{+}$uptake measurements were determined in saline medium containing $140 \mathrm{mM} \mathrm{NaCl}\left(\mathrm{Na}^{+}\right.$ medium) or containing $140 \mathrm{mM} \mathrm{KCl}$ ( $\mathrm{K}^{+}$medium), for $15 \mathrm{~min}$, after the incubation with glutamate. $\left[{ }^{3} \mathrm{H}\right] \mathrm{TPP}{ }^{+}$uptake data indicated by $\mathrm{Na}-\mathrm{K}$ represents the difference of data obtained in $\mathrm{Na}^{+}$and $\mathrm{K}^{+}$ medium. The results are the means \pm SEM of duplicates from five experiments. Statistical significance: $* P<0.05$, $* * P<0.01$, or $* * * \mathrm{P}<.001$ as compared to the respective control; $\mathrm{\dagger P}<0.05$ as compared to the respective data obtained in the presence of glucose.

$10 \mathrm{mM}$ glutamate exposure, in the absence of glucose, showed significantly higher $(P<0.05) \mathrm{TPP}^{+}$uptake values, indicating an increase in membrane potential, as compared to $100 \mu \mathrm{M}$ glutamate (Fig. 3).

\section{Alteration of Cell Viability Following an Acute Exposure to Glutamate under Glucose Deprivation}

Because exposure to glutamate under glucose deprivation was shown to cause significant changes in the 
energy charge (Fig. 1) and in membrane potential (Fig. 3) of retinal cells in culture, we next examined the cell viability under similar experimental conditions, by measuring the leakage of LDH or the efficacy of retinal cells to reduce the MTT salt after glutamate exposure, for $2 \mathrm{~h}$ (Table 1 ).

Glucose deprivation, per se, or exposure to glutamate (up to $10 \mathrm{mM}$ ) in the presence of glucose did not cause a significant alteration in LDH leakage in comparison with control cells incubated with glucose. Under glucosedeprived conditions, exposure to $100 \mu \mathrm{M}$ glutamate significantly increased the release of LDH in comparison to controls (Table 1). Nevertheless, no further increments were observed upon exposure to $10 \mathrm{mM}$ glutamate. The LDH leakage upon incubation with 100 $\mu \mathrm{M}$ glutamate in glucose-free medium (7.45 $\pm 0.75 \%)$ was significantly higher $(P<0.001)$ as compared to the effect of glutamate in the presence of glucose (3.66 \pm $0.37 \%)$. The results indicated that an acute exposure to glutamate, under glucose deprivation, caused some irreversible cell membrane damage.

Analysis of cell viability by the MTT method indicated that glucose deprivation, per se, decreased significantly $(25.1 \pm 1.8 \%$ of control $)$ the efficacy of retinal cells to reduce MTT (Table 1). These results indicate a major decrease of redox efficiency of retinal cells, probably related to mitochondrial functional deficits in the absence of glucose, which was not further affected upon exposure to glutamate.

\section{DISCUSSION}

This study shows that an acute exposure of retinal cells in culture to glutamate, under glucose-deprived conditions, causes significant intracellular alterations in cellular energy charge, intracellular $\mathrm{Ca}^{2+}$ accumulation, and membrane potential. Glucose deprivation alone induced a small decrease in the energy charge (Fig. 1) and a decrement in the cellular redox efficacy, probably related with changes in mitochondrial function $(11,16)$, as determined by the MTT method (Table 1 ). The alteration of cellular redox state may have influenced the reduction in energy charge after incubation with glutamate, because exposure to glutamate potentiated the loss of energy levels in cells deprived of glucose (Fig. 1). A decrement in the energy charge in the absence of glucose may have al so influenced the plasma membrane potential (Fig. 3), which could result from changes in membrane ionic fluxes. Previously, inducers of hypoglycemia-like conditions, such as the iodoacetic acid or deoxyglucose, were shown to significantly decrease the energy charge in cocultures of retinal cells (19). In the retina, Zeevalk and Nicklas (24) have also demonstrated that iodoacetic acid significantly decreases intracellular ATP, phosphocreatine, and lactate levels.

Under glucose-free conditions, exposure to $100 \mu \mathrm{M}$ glutamate, for $2 \mathrm{~h}$, increased significantly the leakage of LDH (Table 1), indicating a decrease of plasma membraneintegrity, which may berelated with changes in energy charge, membrane depolarization, and $\mathrm{Ca}^{2+}$ uptake. Other authors have previously found that metabolic inhibitors predispose the neurons to glutamate toxicity $(18,22,25)$. The excitotoxicity induced by glutamate, either mediated through the activation of the N-methyl-D-aspartate (NMDA) receptor (5) or the non-N MDA receptors (4), has been associated with the accumulation of $\mathrm{Ca}^{2+}$ in the cells. Our data showed that there is an increase in the uptake of $\mathrm{Ca}^{2+}$ induced by glutamate in the presence of glucose $(100 \mu \mathrm{M}$ glutamate increased ${ }^{45} \mathrm{Ca}^{2+}$ uptake by about sixfold as compared to the control, as shown in Fig. 2), suggesting that a large elevation of intracellular $\mathrm{Ca}^{2+}$ does not necessarily predict a major decrease in cell viability, since we did not observe significant changes in LDH leakage (Table 1), an indicator of irreversible membrane damage. In the absence of glucose, $10 \mu \mathrm{M}$ glutamate increased significantly the uptake of $\mathrm{Ca}^{2+}$, as

\section{TABLE 1}

Effect of Glucose Deprivation and Glutamate-Mediated Changes in Retinal Cells Viability

\begin{tabular}{|c|c|c|c|c|c|c|c|c|}
\hline & \multicolumn{4}{|c|}{ +Glucose } & \multicolumn{4}{|c|}{-Glucose } \\
\hline & Control & $10 \mu \mathrm{M}$ Glu & $100 \mu \mathrm{M}$ Glu & $10 \mathrm{mM}$ Glu & Control & $10 \mu \mathrm{M} \mathrm{Glu}$ & $100 \mu \mathrm{M}$ Glu & $10 \mathrm{mM}$ Glu \\
\hline $\begin{array}{l}\text { LDH leakage } \\
\text { (\% of total) } \\
\text { MTT reduction }\end{array}$ & $3.01 \pm 0.30$ & $4.08 \pm 0.79$ & $3.66 \pm 0.37$ & $4.67 \pm 0.44$ & $4.12 \pm 0.41$ & $5.97 \pm 0.46$ & $7.45 \pm 0.75 * * *,+\dagger \dagger$ & $6.99 \pm 0.70^{* *}$ \\
\hline (\% of control) & $100.0 \pm 2.3$ & $87.9 \pm 0.5^{*}$ & $82.7 \pm 2.5^{* *}$ & $90.9 \pm 3.2$ & $25.1 \pm 1.8+\dagger \dagger$ & $28.8 \pm 1.1+\dagger \dagger$ & $27.2 \pm 1.9+1 \dagger$ & $28.8 \pm 2.3+1 \dagger$ \\
\hline
\end{tabular}

Note Retinal cells were incubated in the presence or in the absence of glucose for 30 min and further exposed to glutamate (10 $\mu \mathrm{M}$, $100 \mu \mathrm{M}$, or $10 \mathrm{mM}$ ) for $2 \mathrm{~h}$ with glucose (+glucose) or in glucose-free medium (-glucose), respectively. Cell viability was determined by measuring the leakage of LDH (in \% of total) or the efficacy of retinal cells to reduce the MTT salt (in \% of control, in the presence of glucose). The results are the means \pm SEM of duplicates or quadriplicates from six (LDH leakage) or three (MTT reduction) experiments. Statistical significance: * P < 0.05 , $* * \mathrm{P}<0.01$, or $* * * \mathrm{P}<0.001$ as compared to the controls in the presence or in the absence of glucose; $\mathrm{\dagger} \dagger+\mathrm{P}<0.001$ as compared to the respective experimental condition observed in the presence of glucose. 
compared to experimental conditions in the presence of glucose (Fig. 2). However, no significant differences were observed in cells treated with $100 \mu \mathrm{M}$ glutamate in the presence or in the absence of glucose (Fig. 2). Because hypoglycemia-like conditions induced in the presence of iodoacetic acid, for $15 \mathrm{~min}$, increased the extracellular accumulation of endogenous glutamate (not shown), an alteration in $\mathrm{Ca}^{2+}$ uptake, and cell viability in the presence of low glutamate concentrations might have been conditioned by the releasable pool of the amino acid. Nonetheless, the observation that glucose deprivation, per se, did not affect the uptake of $\mathrm{Ca}^{2+}$ suggests that, after a period of $2 \mathrm{~h}$, the accumulated $\mathrm{Ca}^{2+}$, resulting from activation of ionotropic glutamate receptors by endogenous glutamate, could have been extruded out of the cells. Low $(100 \mu \mathrm{M})$ glutamate concentrations, in the absence of glucose, significantly decreased the membrane potential in retinal cells in culture (Fig. 3), probably resulting from the decrement in energy levels (Fig. 1). Low concentrations of glutamate were also found to preferentially activate the NMDA receptors (5), which may lose the voltagedependent $\mathrm{Mg}^{2+}$ blockade during metabolic inhibition (25), thus contributing to enhance receptor activation (18). These results suggest that under glucose deprivation, one of the primary events to induce excitotoxicity, in the presence of low glutamate concentrations, involves a decrement in energy charge, associated with a decreased redox state of the cells and, eventually, with a decrease integrity of the membrane (Table 1). Because we could not find significant decrements in the glutamate-induced uptake of $\mathrm{Ca}^{2+}$ in the presence of nitrendipine $(5 \mu \mathrm{M})$, a blocker of the L-type voltagesensitive $\mathrm{Ca}^{2+}$-channels (not shown), the increments in $\mathrm{Ca}^{2+}$ accumulation may have resulted from the entry of $\mathrm{Ca}^{2+}$ through the glutamate receptor-associated channels. Ferreira et al. (8) have previously found that the permeation of $\mathrm{Ca}^{2+}$ through the glutamate receptors, and specially that occurring through the NMDA receptor for small $\mathrm{Ca}^{2+}$ loads, correlated well with a subsequent increase in retinal delayed cell death, as determined by the MTT method upon 18-20 h of glutamate exposure. A decrease in the redox state of retinal cells submitted to metabolicinhibition by induction of chemical ischemia, previously shown to increase the release of endogenous glutamate (19), resulted partially from the activation of AMPA ( $\alpha$-amino-3-hydroxy-5-methyl-4isoxazolepropionate)/kainate glutamate receptors (9). In the isolated retina, glutamate, NMDA, AMPA, and kainate were all shown to cause delayed, as well as acute excitotoxic injury (20). Several studies demonstrated a decrease of cell death by using antagonists of NMDA or non-NMDA glutamate receptors, either when cell damage was induced by glutamate exposure $(8,14)$ or by metabolic inhibition $(15,24)$.

By testing $10 \mathrm{mM}$ glutamate, a high extracellular glutamate concentration, expected to occur after cell disruption, when the intracellular constituents gain access to the intersticial space under pathophysiological conditions (12), we showed that neither the energy charge nor the cell viability was affected, as compared to the results observed in the presence of low glutamate concentrations. Nevertheless, the uptake of $\mathrm{Ca}^{2+}$, after exposure of retinal cells to $10 \mathrm{mM}$ glutamate in the absence of glucose, was significantly lower as compared to cells incubated in the presence of glucose (Fig. 2). The observation that maximal $\mathrm{Ca}^{2+}$ accumulation occurred after exposure to $100 \mu \mathrm{M}$ glutamate under glucose deprivation suggested that a partial reduction of cellular energy levels (Fig. 1) may have influenced a bulk entry of $\mathrm{Ca}^{2+}$. Incubation with $10 \mathrm{mM}$ glutamate, in the absence of glucose, also induced a significant increase in $\mathrm{TPP}^{+}$uptake as compared to $100 \mu \mathrm{M}$ glutamate (Fig. 3). Thus, a small, but significant, decrease in membrane depolarization after $10 \mathrm{mM}$ glutamate exposure, under glucose-deprived conditions, could partly explain a decrement in $\mathrm{Ca}^{2+}$ accumulation. We may also consider that the entry of $\mathrm{Ca}^{2+}$ occurring through the glutamate receptors may have decreased in the presence of high glutamate concentrations $(10 \mathrm{mM})$, because NMDA receptor activation depends on cell depolarization.

In conclusion, we demonstrate that glucose deprivation and a decrement in energy levels, probably associated with a decrement in mitochondrial function, predispose retinal neurons to glutamate injury after an acute exposure. Glucose deprivation induced a reduction in the energy charge and a decrease in membrane potential, which may be responsible for an increase in $\mathrm{Ca}^{2+}$ entry into the cells in the presence of low glutamate. Interestingly, the present data also suggest the possibility that retinal neurons may have "adaptive" mechanisms to overcome excitotoxic effects induced by high extracellular glutamate concentrations, because in cells exposed to glucose deprivation, the decrease in the energy charge or the accumulation of $\mathrm{Ca}^{2+}$ were not enhanced upon addition of $10 \mathrm{mM}$ glutamate, as compared to $100 \mu \mathrm{M}$ glutamate. Furthermore, membrane depolarization decreased in cells exposed to $10 \mathrm{mM}$ glutamate under glucose deprivation, which could explain a maintenance of $\mathrm{Ca}^{2+}$ accumulation, as compared to $100 \mu \mathrm{M}$ glutamate. These data also suggest the possibility of a decreased activation of NMDA glutamate receptors, thus avoiding major intracellular changes. Although not reflecting changes occurring on delayed retinal cell death, the present results may be important in determining the intracellular mechanisms associated with glutamate-mediated neuronal injury that occur under acute hypoglycemia or metabolic compromised conditions, which can predispose to further cell degeneration. 


\section{ACKNOWLEDGMENTS}

This work was supported by J NICT (Portuguese Research Council) and by the Human Capital and Mobility program (EU).

\section{REFERENCES}

1. Agostinho, P., C. B. Duarte, A. P. Carvalho, and C. R. Oliveira. 1994. Effect of oxidative stress on the release of $\left[{ }^{3} \mathrm{H}\right] \mathrm{GABA}$ in cultured chick retina cells. Brain Res. 655: 213-221.

2. Agostinho, P., C. B. Duarte, and C. R. Oliveira. 1995. Influence of oxidative stress on membrane potential and on $\mathrm{K}^{+}$channels in neuronal cells. Bioel ectrochem. Bioenerg. 38: 297-305.

3. Atkinson, D. E. 1968. Regulation of enzyme function. Annu. Rev. Microbiol. 23: 47-68.

4. Brorson, J. R., P. A. Manzolillo, and R. J. Miller. 1994. Ca ${ }^{2+}$ entry via AMPA/KA receptors and excitotoxicity in cultured cerebellar Purkinje cells. J . Neurosci. 14: 187-197.

5. Burgard, E. C., and J . J . Hablitz. 1995. N-methyl-D-aspartate receptor-mediated calcium accumulation in neocortical neurons. Neuroscience 69: 351-362.

6. Duarte, C. B., P. F. Santos, and A. P. Carvalho. 1996. $\left[\mathrm{Ca}^{2+}\right]_{i}$ regulation by glutamate receptor agonists in cultured chick retina cells. Vision Res. 36: 1091-1102.

7. Faden, A. I., P. Demediuk, S. S. Panter, and R. Vink. 1989. The role of excitatory amino acids and NMDA receptors in traumatic brain injury. Science 244: 798-800.

8. Ferreira, I. L., C. B. Duarte, and A. P. Carvalho. 1996. Ca ${ }^{2+}$ influx through glutamate receptor-associated channels in retina cells correlates with neuronal cell death. Eur. J. Pharmacol. 302: 153-162.

9. Ferreira, I. L., C. B. Duarte, and A. P. Carvalho. 1997. 'Chemical ischemia' in cultured retina cells: The role of excitatory amino acid receptors and of energy levels on cell death. Brain Res. 768: 157-166.

10. Huba, R., and H. D. Hofmann. 1990. Identification of GABAergic amacrine cell-like neurons developing in chick retinal monolayer cultures. Neurosci. Lett. 117: 37-42.

11. Keller, J . N., Z. Pang, J . W. Geddes, J . G. Begley, A. Germeyer, G. Waeg, and M. P. Mattson. 1997. Impairment of glucose and glutamate transport and induction of mitochondrial stress and dysfunction in synaptosomes by amyloid $\beta$-peptide: role of the lipid peroxidation product 4-hydroxynonenal. J . Neurochem. 69: 273-284.

12. Kempski, O. S., and C. Volk. 1994. Neuron-glial interaction during injury and edema of the CNS. Acta Neurochim. 60: 7-11.
13. Lichtshtein, D., H. R. Kaback, and A. J . Blume. 1979. Use of a lipophilic cation for determination of membrane potential in neuroblastoma-glioma hybrid cell suspensions. Proc. Natl. Acad. Sci. USA 76: 650-654.

14. Michaelis, R. L., and S. M. Rothman. 1990. Glutamateneurotoxicity in vitro: antagonists pharmacology and intracellular calcium concentrations. J . Neurosci. 10: 283-292.

15. Monyer, H., M. P. Goldberg, and D. W. Choi. 1989. Glucose deprivation neuronal injury in cortical culture. Brain Res. 483: 347-354.

16. Mosmann, T. 1983. Rapid colorimetric assay for cellular growth and survival: Application to proliferation and cytotoxicity assays. J . Immunol. Methods 65: 55-63.

17. Neal, M. J ., J . R. Cunningham, P. H. Hutson, and J . Hogg. 1994. Effects of ischaemia on neurotransmitter release from isolated retina. J . Neurochem. 62: 1025-1033.

18. Novelli, A., J. A. Reilly, P. G. Lysko, R. C. Henneberry. 1988. Glutamate becomes neurotoxic via the N-methyl-D-aspartate receptor when intracellular energy levels are reduced. Brain Res. 451: 205-212.

19. Rego, A. C., M. S. Santos, and C. R. Oliveira. 1996. Oxidative stress, hypoxia, and ischemia-like conditions increase the release of endogenous amino acids by distinct mechanisms in cultured retinal cells. J . Neurochem. 66: 2506-2516.

20. Romano, C., M. T. Price, and J. W. Olney. 1995. Delayed excitotoxic neurodegeneration induced by excitatory amino acid agonists in isolated retina. J . Neurochem. 65: 59-67.

21. Sedmak, J . J ., and S. E. Grossero. 1977. A rapid sensitive and versatile assay for protein using Coomassie Brilliant Blue G250. Anal. Biochem. 79: 544-552.

22. Schurr, A., R. S. Payne, M. F. Heine, and B. M. Rigor. 1995. Hypoxia, excitotoxicity, and neuroprotection in the hippocampal slice preparation. J . Neurosci. Methods 59: 129-138.

23. Stocchi, V., L. Cucchiarini, L. Chiarantini, P. Palma, and G. Crescentini. 1985. Simultaneous extraction and reverse-phase high-performance liquid chromatographic determination of adenine and pyridine nucleotides in human red blood cells. Anal . Biochem. 146: 118-124.

24. Zeevalk, G. D., and W. J. Nicklas. 1990. Chemically induced hypoglycemia and anoxia: Relationship to glutamate receptormediated toxicity in retina. J. Pharmacol. Exp. Ther. 253: 1285-1292.

25. Zeevalk, G. D., and W. J . Nicklas. 1992. Evidence that the loss of the voltage-dependent $\mathrm{Mg}^{2+}$ block at the $\mathrm{N}$-methyl-D-aspartate receptor underlies receptor activation during inhibition of neuronal metabolism. J . Neurochem. 59: 1211-1220. 